\title{
Militating Factors Against the Practice of Green Building as a New Paradigm in Construction Projects
}

\author{
Nkeleme Emmanuel Ifeanyichukwu ${ }^{1}$, Nwabueze Micheal Anosike ${ }^{1}$, Achigbu Onyemaeze Ikenna ${ }^{1}$, \\ Ukwunna Okechukwu Chidiebere ${ }^{2}$
}

${ }^{1}$ Department of Building, School of Environmental Sciences, Federal University of Technology, Owerri, Nigeria

${ }^{2}$ Department of Architecture, School of Environmental Sciences, Federal University of Technology, Owerri, Nigeria

Email address:

Emmanuel.nkeleme@futo.edu.ng (N. E. Ifeanyichukwu), Nwabueze.anosike@futo.edu.ng (N. M. Anosike),

onyemaachigbu@gmail.com (A. O. Ikenna),Bbujo0718@yahoo.com (U. O. Chidiebere)

\section{To cite this article:}

Nkeleme Emmanuel Ifeanyichukwu, Nwabueze Micheal Anosike, Achigbu Onyemaeze Ikenna, Ukwunna Okechukwu Chidiebere. Militating Factors Against the Practice of Green Building as a New Paradigm in Construction Projects. International Journal of Sustainable and Green Energy. Vol. 10, No. 1, 2021, pp. 13-18. doi: 10.11648/j.ijrse.20211001.13

Received: January 5, 2021; Accepted: January 19, 2021; Published: January 28, 2021

\begin{abstract}
The green construction techniques is a relatively new building philosophy with an unprecedented opportunity to in the global carbon reduction targets as well as pushing the application of more environmentally friendly materials, strategies of saving resources, lower waste production, and the improvement of indoor environmental quality, among others. However, this technique is faced with many pullbacks especially in Nigeria. Hence, the paper sought to assess the militating factors against the practice of green building as a new paradigm in construction projects. The research implored the combination of a quantitative and qualitative approach. The focus was on the buildings within FUTO with more concentration of new buildings constructed between 2012 and 2017 . The primary data was obtained through observations and by administering questionnaires to lecturers familiar with the design, construction and management of the buildings. For quantitative method, parameters that define green construction with a range of variables from minimal to complete incorporation of the elements, determined the degree of conformity. The result from the research revealed that, to a 'Great extent', lack of enforcement and limited research were the greatest militating factor facing practitioners in the adoption of green building concept with these two factors having relative importance index (RII) of 0.81 and 0.79 respectively. Lack of awareness (0.63) was a moderate challenge practitioners faced in the adoption of the concepts. The research recommends that suitable policy, structure and consequence be put in place to enforce green building concept as well as opportunity for continuous research in this field.
\end{abstract}

Keywords: Green Building, Construction, Challenges, Environment Friendly, Development

\section{Introduction}

Developing countries such as Nigeria is not exempted in the challenge of the growth of public building sector accompanied by pressure on power, water, natural and processed material consumptions due to increased urbanization. This increasing urbanization is linked to the loss of arable land, material and water crisis, and serious environmental problems like air pollution, noise pollution and waste generated from buildings. The construction industry response with green building to its guilt of some practice is to ensure and promote environmental sustainability. In spite of all the glaring challenges and measures, many nation are not swift in embracing the practice of Green Building developments and sustainable with Nigeria's construction industry inclusive. This calls for concern and inquiry of the factors affecting the sustainable practices within its built environment.

The term "green" and "sustainable" constructions are often used interchangeably, even though there are shades of meaning implied by each. Sustainable construction has emerged as a guiding model to create a sustainable kind of built environment: "one that meets the needs of humans in the present without limiting the ability of future generations to meet their own needs" [16]. The creation, operation and 
disposal of the built environment dominate humanity's impact on the natural world [10]. For Nigeria, construction is unequivocally, a key sector of the economy, not merely because of its 3\% GDP contribution, but because of its contribution towards reducing the rate of unemployment and its corresponding effects on other economic activities [13]. Unfortunately however, the Nigerian construction industry is also infamous for its adverse effect on sustainable development. For example, Nwokoro, reiterating Woolley, maintained that the construction industry remains the leading destroyer of the environment, resulting as a major consumer of non- renewable resources, produces substantial waste, pollutes air and water, and contributes to land dereliction in no small way [23].

The construction industry is a major consumer of resources and a major producer of waste. According to Agenda 21, the industry is often referred to as the 40 per cent industry as it is responsible for the consumption of approximately 40 percent of natural resources and about 40 per cent of all waste produced [5]. Gandu, observed that buildings contributes to environmental crises via resources depletion, energy consumption, air pollution and massive creation of waste [7]. Ajatar, Identified up to ten different resulting effects of construction activities on the environment [2]. These include, among others, land misuse, existing habit destruction, site dereliction, misuse of natural resources, to mention but a few. In addition, a number of health and comfort disturbances results from construction on-site practices, particularly to people living where construction activities are taking place.

One of the challenges of great concern is the observation made by Schmidt that building construction activities accounts for approximately one-third of ecological disasters. According to Kolawole and Anigbogu, the friendliest way to handle the environmental challenges resulting from construction of building is not to quit building because without construction, life can be miserable and threatening. For shelter is needed, amongst other things, for protection against the inclement weather and for healthy living, state that what is needed is a dynamic equilibrium [11]. In other words, environmentally friendly building production process that possess no threat to the ecosystem yet competitive should be encouraged [25]. Thus, Green Buildings (GB) is an environmentally friendly buildings, sustainable or highperformance buildings, seem to satisfy the above mentioned requirements.

Similarly, Green building also known as green construction or sustainable building refers to a structure and using process that is environmentally responsible and resource-efficient throughout a buildings life-cycle from sitting to design, construction, operation, maintenance, renovation, and demolition [21]. Green Building requires close synergy among design team, the architects, the engineers and the client at all project stages [8]. The green building practice expands and complements the classical building concerns of economy, utility, durability, and comfort [21].
Some of the benefits of Green building measures ranges from lower building operating expenses through reduced utility and waste disposal. Cost, and also to lower on-going building maintenance cost ranging from salaries to suppliers. The emphasis is on efficiency. Sustainability is a goal that allows for the continuing improvement of standard of living without reversible damage to resources we need to survive as species [12]. The green approach to Architecture is not something new as it has existed for years. What is new is the realization that green approach to the built environment involves a holistic approach to the design of buildings; that all the resources that go into a building, are their materials fuels or the contribution of the users need to be considered if sustainable architecture is to be produced [4].

A lot of prospect exist in embracing green or sustainable concept in design ranging from; reducing energy, reduce building related illness, operation and maintenance cost, increase the productivity and comfort of building occupants, reduce waste and pollution and increase building and component durability and flexibility. It is important that the focus of green concept be embraced from the early stages of building, planning and construction. Furthermore, green buildings squarely address the spotty performance of conventional buildings with respect to human health. There is ample evidence that $40 \%$ of all illnesses can be traced to buildings and homes where people live, work, or attend school, church or sporting events [1]. Issues of Sick Building Syndrome (SBS) or Building Related Illness (BRI) are often ignored by the Conventional construction, unless forced to by lawsuits. Green buildings meet the challenges of building health directly and provide several layers of consistent approaches that promote occupant health.

\section{Literature Review}

Green Building (GB) is a larger part of the concept of sustainable development that is holistic in its approach approach to programming, planning, designing, and constructing (or renovating) buildings. It helps tackle the negative side effects of construction activities. It handles all liabilities of materials, water and energy waste, and pollution emissions by converting it into economic opportunities through the realization of environmentally sound, healthier and cost effective project. Green Building approach has been described as a clear answer to the challenges of environmental health, economic and construction problems [22]. Construction using Green Building approach entails tailoring a building and the site to the local climate, site conditions, cultural and community in order to reduce resource consumption, augment resource supply, and enhance the quality and diversity of life. To achieve this, it requires analyzing important and interrelated issues, such as, building orientation and form, the site and climate, lighting and thermal control system, and materials, while optimizing all these in an integrated design.

Furthermore, Green Building approach is a total quality management approach to building which harnesses the input 
of all the key people involves right from the beginning of the project and at various stages of the execution of such project. This enables synergy from design through the interdisciplinary teamwork. Thus, Green Building as rightly observed by Karolides, it is neither, an assemblage of environmental' components nor a piecemeal modification of an already designed standard building. It is neither a building style in which the building (Green Building) is expected to assume certain form or to have a "characteristic look". Rather, it is a building philosophy in which natural and resource efficient features are incorporated in a building.

Arguably, that Green Building makes an attempt to maximize operational energy savings, provide optimally healthy interior and limit the negative impact of construction activities, the professionals that usually participate in the construction of Green Building, increases considerably. For example, according to Karolide, Green Building design can take $40-100 \%$ more effort on the part of mechanical engineer or energy analyst [9]. Regarding the construction site selection, since emphasis is made on resource conservation and cultural preservation, renovating an existing building is preferred to new building.

Also Green Building development should be given priority to site with adequate water sources and access to renewable energy like biomass, solar, and geothermal.

On the other hand, ecologically sensitive land, suitable for agriculture, land of historical or cultural importance, or site that is prone to danger such as, flood, and wild fire should be avoided. Relative to what is obtained in towns in Nigeria, where there is the Government Reserved Area (GRA). Materials to be used for the construction of (GB) are those that would ensure the achievement of sustainable built environment. This also applies to the actual construction of building that explains the reason why a Builder who is regarded as the "brain - box" of the project is expected to, among other things, carry out buildability and maintainability analysis, prepare production management document (PMD), develop elaborate plan for waste management even before the actual execution of the project.

Challenges Hindering the Uptake of Green Building Concept

Every project or development comes with its unique benefits, challenges and factors that hindered its success; Green Building developments in Nigeria are not an exception. Among the challenges highlighted by Sultan, is urban planning. Most urban buildings are densely constructed and prevent air movement after construction. Planning the site is significant element of sustainable building as the construction process has a significant impact on several sustainability aspects. Most of the time large green areas are destroyed instead of integrating them in the built environment [20].

Ajatar, argues that in many urban areas of Africa and especially in the cities, construction of buildings generally, but especially residential buildings has been carried out to occupy the entire site. The natural green system has been destroyed and compaction has taken place to a level that prevents air movement even after construction is completed. The existing natural environment has in many cases been destroyed beyond repair. Industry professionals, in both the design and construction disciplines, are generally slow to change, tend to be risk-adverse, lack sound knowledge, experience, and understanding of how to apply ecology to construction design; moreover, environmental or economic benefit of some green building approaches has not been scientifically quantified.

Incompatibility of interests amongst stakeholders caused conflicts and disputes in construction [6]. Incorporating the various interests of stakeholders should be extremely important for the preparation of green specifications, construction and maintenance [3]. Green Building projects design and construction is new in Nigeria and is characterized by the problem of lack of shared perception and agreement on the objectives and success/failure of the green building projects by stakeholders [17]. However, recognition of (soft issues) Economic and Social sustainability concerns as well as Cultural heritage of the built environment as being equally important; Sustainable world progress is dependent upon continued Economic, Social, Cultural, and Technological progress [19]. These four main factors; Economic, Social, Cultural and Technological factor, each of which is found to have a significant effect towards adopting Green Building Technology [14].

The awareness of green building by the public will form the market driven power for such developments especially in the urban area. However, the difficulties include: Some of these challenges may include insufficiency / lack of; urban planning and land use policy, financial instruments for green buildings, enforcement of sustainable building policies, education on green building concepts, limited research on green building concepts, empowerment of stake holders, and lack of incentives from the government.

\section{Research Methodology}

This study was conducted through a survey research design and made use of both qualitative and quantitative modes of inquiries to assess the conformity of FUTO buildings to green building principles. According to [15], a combination of qualitative and quantitative methods is advantageous because they supplement each. Quantitative methods provide hard data whereas qualitative methods provide in depth explanations therefore the findings derived from one method validates the other.

The focus was on the buildings within FUTO with more concentration of new buildings constructed between 2012 and 2017 as relates to the scope of this study. FUTO have experienced a steady rise in the number of institutional buildings in the last five years. The primary data was obtained through observations and by administering questionnaires to individuals who are lecturers, familiar with the design, construction and management of the buildings. For quantitative method, parameters that define green construction with a range of variables from minimal to 
complete incorporation of the elements determined the degree of conformity. The degree of adoption was statistically analysed on the sampled buildings.

Two complexes were identified for this study in SEET complex and SMAT complex in FUTO as indicated in appendix 2. The choice of these two areas was informed by the fact that over $80 \%$ of major lecture hall buildings have been constructed in these two locations between the periods of the study. To maintain uniformity, premises that were sampled were limited to at least two floors and above. This ensured that the composition of the accessible population had the same characteristics hence homogeneous. SEET Complex construction commenced September 2011 and was completed July 2012. While SMAT Complex commenced October 2013 and completed February 2016. (By the then Vice Chancellor, Prof. Chigozie Cyril Asiabaka 2011-2016)

Due to time and resource constraints, the study was restricted to a portion of the target population of FUTO, [12]

Finite Population: for a known population size of 162 .

$$
n=\frac{N}{\left(1+N e^{2}\right)}
$$

Where ' $\mathrm{n}$ ' is the sample size

' $N$ ' is population size $=162$

Note; using a confidence level of $95 \%$

' $\mathrm{e}$ ' is alpha level $=0.05$

Mathematically; $n=\frac{N}{\left(1+N e^{2}\right)}=n=\frac{162}{\left(1+162\left(0.05^{2}\right)\right)} \quad=115$ sample size.

Questionnaires designed in the form of a likert scale with closed and open ended questions were directed to different respondents which included Architects, Engineers, Project Managers, Builders, Planners, Environmentalist and Surveyors behind the sampled buildings. A 5-point Likert scale Questionnaire format (Very Great $=5$, Great $=4$, Moderate $=3$, Little $=2$, Not at all=1) was used to obtained the various perceptions of the professionals working in the Nigeria's Built Environment in FUTO. An inspection checklist that defines green construction with a range of variables from minimal to complete incorporation of the elements was prepared to determine the degree of conformity. Frequency and percentage count tables, Mean item score and Relative Importance Index (RII) and Ranks were used for data analyses.

\section{Findings and Discussions}

In this study a sample size of 115 respondents from two sampled complexes was expected $(n=115)$ from Builders, Architects, Quantity surveyors, Town Planner, Land Surveyor, Environmentalist and Engineers, respectively. Data was obtained from self-administered questionnaires, completed by 91 participants $(n=91)$, this constituted a $79 \%$ response rate. Percentages reported correspond to the total number of lecturers in the building profession who answered the individual questions. Although neither the reasons for non-participation nor the characteristics of the nonrespondents are known.
Table 1. Distribution of Questionnaires.

\begin{tabular}{lll}
\hline Questionnaire & Frequency & $\begin{array}{l}\text { Percentage } \\
(\mathbf{\%})\end{array}$ \\
\hline Number properly completed and returned & 91 & 79.0 \\
Numbers not returned & 24 & 21.0 \\
Total Number distributed & 115 & 100 \\
\hline
\end{tabular}

Source: Survey, 2017

\subsection{Response to Questionnaires}

Questionnaires were sent out to lecturers in the building profession who have the knowledge in the design and implementation of 2 sampled complexes. The corresponding responses received are tabulated and represented graphically in figure 1.

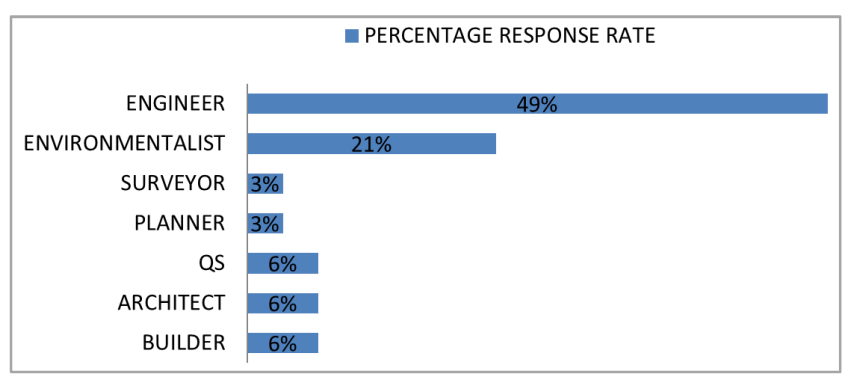

Source: Survey, 2017

Figure 1. Response to questionnaires.

The Engineers comprising of the civil, electrical and mechanical gave the highest response of $49 \%$ followed by the Environmentalists by $21 \%$. The Quantity Surveyors, Architects and Builders were all on $6 \%$ each while the Land Surveyor and Urban planner were 3\% each. However, the low response rate was as a result of few respondents from those departments.

Professional Experience

Table 2. Respondents Professional Experience.

\begin{tabular}{lll}
\hline Experience & Frequency & Percentage (\%) \\
\hline Below 5 years & 5 & 7 \\
$6-10$ years & 32 & 36 \\
$11-15$ years & 5 & 7 \\
$16-20$ years & 27 & 29 \\
Over 20 years & 22 & 21 \\
Total & 91 & 100 \\
\hline
\end{tabular}

Source: Survey, 2017

As it can be observed from table 2, the highest percentage of experience is $36 \%$ and $29 \%$, which is between $6-10$ years and 16-20 years of working experience respectively. The least experience level from the respondents is below 5 years and $11-15$ years having $7 \%$ each.

\subsection{Challenges to the Adoption of Green Building Concepts}

Some factors militating against the construction of Green Building identified from literature were assessed with respect to their severity or importance on a 5 point Likert scale. Table 3 indicates responses from questionnaire on the factors 
hindering the practice of Green Building, on a scale of 1 to 5 ranging from; 'Not at all' to 'Very great extent'. A mean score was calculated and relative importance index (RII); where a higher RII meant that the factor posed a high challenge whereas a lower RII was interpreted as a less challenge in adopting the concept. Lack of enforcement of sustainable building policies $(\mathrm{RII}=0.81$ ) has the highest rating. This suggests that Green Building is relatively a new trend. The respondents regard it as significant problem of Green Building practice largely'.

The study revealed that Limited research on green building concepts was rated $2^{\text {nd }}$ highest with RII of 0.79 which is to a great extent is a challenge. Lack of education on Green Building Concepts (0.78), lack of financial instrument for green building (0.77) and lack of incentives from government $(0.67)$ were all closely ranked as $3^{\text {rd }}, 4^{\text {th }}$, and $5^{\text {th }}$ respectively. Lack of empowerment from stakeholders (0.75), lack of urban planning (0.72) and lack of awareness (0.63) were ranked the least respectively. This is as a result of the scope of study being a government property and as such is less significant to the measure challenges hindering the increased adoption of Green Building Concepts.

Table 3. Militating Factors against the Practice of Green Building.

\begin{tabular}{|c|c|c|c|c|c|c|c|c|c|c|}
\hline \multirow{2}{*}{ Factors } & \multicolumn{5}{|c|}{ Frequency } & \multirow{2}{*}{$\sum \mathbf{f}$} & \multirow{2}{*}{$\sum \mathbf{f x}$} & \multirow{2}{*}{ Mean } & \multirow{2}{*}{ RII } & \multirow{2}{*}{ Rank } \\
\hline & 1 & 2 & 3 & 4 & 5 & & & & & \\
\hline Lack of urban planning and land use policy & 5 & 18 & 14 & 27 & 27 & 91 & 326 & 3.58 & 0.72 & $7^{\text {th }}$ \\
\hline Lack of financial instruments for Green buildings & - & 14 & 18 & 27 & 32 & 91 & 350 & 3.85 & 0.77 & $4^{\text {th }}$ \\
\hline Lack of enforcement of sustainable building policies & - & 14 & 14 & 18 & 45 & 91 & 367 & 4.03 & 0.81 & $1^{\text {st }}$ \\
\hline Lack of education on green building concepts & - & 5 & 18 & 50 & 18 & 91 & 354 & 3.89 & 0.78 & $3^{\text {rd }}$ \\
\hline Limited research on green building concepts & - & 5 & 27 & 27 & 32 & 91 & 359 & 3.95 & 0.79 & $2^{\text {nd }}$ \\
\hline Lack empowerment of stake holders & - & 14 & 27 & 18 & 32 & 91 & 341 & 3.75 & 0.75 & $6^{\text {th }}$ \\
\hline Lack of awareness & 5 & 36 & 18 & 5 & 27 & 91 & 286 & 3.14 & 0.63 & $8^{\text {th }}$ \\
\hline
\end{tabular}

$1=$ Not at all, $2=$ Little extent, $3=$ Moderate extent, $4=$ Great extent, $5=$ Very great extent

Source: Survey, 2017

\section{Conclusion and Recommendations}

It is necessary to be able to measure and verify their performance in an attempt to assess the sustainability of buildings and construction activities. Certain criteria and rating systems have been designed that provide an indication of the performance of buildings and construction activities in terms of sustainability. The essence of these systems are; to aid the design of sustainable buildings and to help evaluate the sustainability of buildings, however they can be faced by resistance (militating factors), which this research assessed.

The study revealed that to a 'Great extent', lack of enforcement and limited research were the greatest hindrance facing practitioners in the adoption of green building concept with these two factors rank one and two with a relative importance index (RII) of 0.81 and 0.79 respectively. Lack of awareness (0.63) was a moderate challenge practitioners faced in the adoption of the concepts. The research recommends that suitable policy, structure and consequence be put in place in the enforcement of green building concept as well as opportunity for continuous research in this field.

\section{References}

[1] Achyuthan A, Balagopal T S P (2006) - Green Architecture Traditional and Modern 'A paper presented at the 22nd National Convention of Architectural Engineers organized by The Institution of Engineers (India) at Trichur during November 1-2, 2006.

[2] Ajatar, U. (2000) - "Project Impacts and Mitigation - A challenge for Nigerian Construction Practioners in the 3
Millennium” Environmental Review, Vol. 3 (2), 343-349.

[3] Berke, P. R., 2002 - Does sustainable development offer a new direction for planning? Challenges for the twenty-first century? Journal of Planning Literature 17, 21-36.

[4] Brenda and Vale, R. (2007) - Principles of Green Architecture. The Sustainable Urban Development..

[5] Dahiru, D. (2005) - "Measures of Ensuring Sustainability in the Nigerian Construction Industry." A Paper Presented at the 2nd National Conference Towards Sustainable Built Environment. Ahmadu Bello University, Zaria - Nigeria. Sept. 21 st -23 rd.

[6] Fenn, P., Lowe, D., Speck, C. (1997) - Conflict and dispute in construction. Construction Management and Economic.

[7] Gandu, Y. J. (2005) - "Environmental Management Tools for Sustainable Development.” A Paper Presented at the National Conference Towards a Sustainable Built Environment. Ahmadu Bello University, Zaria - Nigeria. Sept. 21st - 23rd.

[8] Ji, Y. and Plainiotis, S. (2006) - Design for Sustainability. Beijing: China Architecture and Building Press. ISBN 7-11208390-7.

[9] Karolides, A. (2002) - Project Planning \& Cost Estimating, In: Green Building Approaches in Green Building RS Means Co Ltd; USA Pp 1-22.

[10] Kibert, C., Sendzimir, J., and Guy, G. B. (Eds.). (2000) Defining an Ecology of Construction. Construction Ecology: Nature as the Basis for Green Buildings. New York: Spon Press, 7-28.

[11] Kolawole, J. and Anigbogu (2005) - "Impact of Construction Activities on the Environment." A Paper Presented at the National Conference Towards a Sustainable Built Environment. Ahmadu Bello University, Zaria - Nigeria. Sept. $21 \mathrm{st}-23^{\text {rd }}$. 
[12] Lehrer, D. (2001) - Facility Design and Management Handbook. McGraw-Hill New-York.

[13] NBS, 2014 - Macro-economic data. [Online] Available at: http://nigeria.prognoz.com/ [Accessed 10 November 2014].

[14] Nuruddeen Usman and Usman Mohammed Gidado (2015) An Assessment of the Factors Affecting Green Building Technology (GBT) Adoption. WASET 18th IC Jeddah Saudi Arabia Jan 26-27, 2015, 13 (01) Part XIII.

[15] Nwokoro, I. \& Onukwube, H., 2011 - Sustainable or Green Construction in Lagos, Nigeria: Principles, Attributes and Framework. Journal of Sustainable Development, 4 (4), pp. 166-174.

[16] Ofori, G. (2000) - Challenges of Construction Industries in Developing Countries: Lessons from various Countries. Proceedings of The 2nd International Conference of the UB TG29 On Construction In Developing Countries Challenges facing The Construction Industry in Developing Countries 1517, November 2000, Gabarone, Botswana, 1-3.

[17] Salisu Gidado Dalibi and Hassan Ali Kumo (2016) - Success Criteria for Green Building Projects in the Nigeria's Construction industry: "The Stakeholders' perception".

[18] Schmidt, (2000) - Toward Healthy and Environmentally Oriented Construction Practices in Ukraine Housing Environments Umbruch, 250-256.
[19] Shelbourn A., Bouchlaghem, D. M., Anumba, C. J., Carillo, P. M., Khalfan, M. M. K., Glass, J., (2006) - ITcon Vol. 11 (2006), available at http://itcon.org/2006/4/ pg.57.

[20] Sultan, M K. (2005) - The Construction Industry in Yemen: Towards Economic Sustainability. A Thesis Submitted in Partial fulfilment of the requirement for Doctor of Philosophy.

[21] U.S. Environmental Protection Agency (2009) - Green Building Basic Information http://www.epa.gov/greenbuilding/pubs/about.htm Retrieved June 19, 2015.

[22] Walker, H. (2002) - Design of Green Building in: Green Building: Approaches in Green Building RS Means Co. Ltd USA.

[23] Wallbaum, H, and Buerkin, C. (2003) - Concepts and Instruments for a Sustainable Construction Sector. Industry and Environment: Sustainable Building and Construction. United Nations Environment Programme, 26 (2-3): 53-57.

[24] Woolley, T., 2000 - Green Building: Establishing Principles. Ethics and the Built Environment.. 1 ed. London: Rutledge.

[25] Zubairu, S. (2012) - The Importance of Evaluation and Sustainability in the Built Environment In: Laryea, S., Agyeponng, S., leiringer, R. and Hughes, W. (Eds) Procs 4th West Africa Built Environment Research (WABER) Conference, 24 - 26 July Abuja, Nigeria, 9-13. 